\title{
Analisis Pengambilan Keputusan dan Strategi Pemasaran di Tingkat Kebutuhan Kelor Indonesia (Kasus Agribisnis: Kelor Madura)
}

\author{
Wira'artha I.C., Negoro N.P., dan Prasetyo E.N. \\ (ITS) \\ e-mail: cendickya13@mhs.mb.its.ac.id
}

Departemen Manajemen Bisnis, Fakultas Bisnis dan Manajemen Teknologi, Institut Teknologi Sepuluh Nopember

\begin{abstract}
Abstrak-Kelor adalah tanaman yang tumbuh di dataran tropis, terutama di Indonesia. Bisnis kelor telah menjadi tren bisnis baru di Indonesia. Potensi kelor yang bagus namun belum tereksplor secara mendalam di bidang pemasaran menjadi salah satu hambatan. Kebijakan pengambilan keputusan untuk menjual barang tepat pada konsumen tepat di waktu yang tepat dibutuhkan untuk menghadapi persaingan pemasaran secara global. Penelitian ini bertujuan memetakan pengambilan keputusan dan mengidentifikasi strategi pemasaran pada perusahaan kelor Madura. Data didapatkan dari hasil wawancara terhadap pemilik perusahaan kelor. Hasil dari penelitian ini adalah alur pengambilan keputusan dan perbandingan strategi pemasaran kelor pada perusahaan agribisnis kelor Madura
\end{abstract}

Kata Kunci-Kelor, Strategi Pemasaran, Pengambilan Keputusan.

\section{PENDAHULUAN}

$\mathrm{K}^{\mathrm{n}}$ ELOR merupakan tanaman yang diketahui memiliki 13 spesies dari pohon kelor yang berada dalam family Moringaceae. Penelitian mengenai manfaat daun kelor telah banyak dilakukan oleh peneliti seluruh dunia sebagia tanaman yang bisa dimanfaatkan dan dikomersialisasikan mulai dari bibit, daun, batang dan akar [1]. Hambatan paling krusial dalam pengembangan komersial kelor adalah pemasaran. Di mana pemasaran kelor memerlukan usaha, sumber daya lebih dan strategi cukup matang dan tidak sembarangan untuk masuk ke dalam pasar kelor [2]. Meskipun tren bisnis kelor yang menarik dan penetrasi pemasaran kelor ke dalam pasar sulit, industri kelor di Indonesia tetap bertahan dan beradaptasi dengan lingkungan bisnis. Lalu, apa kunci kesuksesan industri ini dapat bertahan di Indonesia?

Penelitian ini membahas mengenai proses pengambilan keputusan dan strategi pemasaran dari eksekutif atau pemilik perusahaan agribisnis kelor selama beberapa tahun silam. Menggunakan metode wawancara mendalam, personal, dan tatap muka kepada para eksekutif memberikan pandangan baru terhadap proses strategi pemasaran perusahaan agribisnis kelor untuk beradaptasi pada iklim bisnis di Indonesia. Untuk memberikan struktur terhadap pandangan ini, analisis jalur memetakan keputusan tidak terstruktur digunakan dalam penelitian ini. Model pengambilan keputusan Mintzberg et.al memberikan gambaran untuk menunjukkan permasalahan atau kesempatan, alternatif pengembangan, dan alternatif seleksi [3]. Selama beberapa tahun ini, industri kelor beradaptasi pada metode promosional, penyesuaian produk dan membuat kolaborasi terhadap instansi terkait. Perubahan ini memberikan hasil pada kesadaran pelanggan dan memberikan bukti bahwa industri kelor memiliki pertumbuhan positif di tahun berikutnya.

Temuan penelitian ini mendukung pentingnya metodologi kualitatif dalam memahami pengambilan keputusan bisnis. Penelitian ini memberikan pandangan unik untuk membangun teori dan mengoleksi intrepretatif data yang dapat dipelajari mengenai strategi pemasaran dua tipe perusahaan kelor.

\section{LANDASAN TEORI}

\section{A. Kelor}

Kelor merupakan tanaman milik family dari Moringaceae, yang memiliki satu genus di antara 13 spesies pohon gugur [4]. Pohon kelor berbentuk ramping dengan cabang yang bisa tumbuh sampai ketinggian 10 meter dan tumbuh di daerah tropis yang panas atau semi-kering. Kelor berperan penting dalam menyelesaikan permasalahan nutrisi dan berbagai penyakit di Dunia. Semua bagian dari pohon kelor dapat dimakan dan telah lama dikonsumsi oleh manusia [5].

\section{B. Strategi Pemasaran}

Strategi pemasaran adalah sebuah rencana yang memungkinkan perusahaan mengoptimalkan penggunaan sumber dayanya untuk mencapati tujuan pemasaran dan perusahaan [6]. Isu strategi pemasaran adalah seleksi evaluasi pasar sasaran dan merancang susunan bauran pemasaran. Bauran pemasaran adalah serangkaian variabel yang dapat dikontrol dan tingkat variabel yang digunakan oleh perusahaan untuk memengaruhi pasaran yang menjadi sasaran [7].

\section{Pengambilan Keputusan}

Pengambilan keputusan merupakan proses dalam menghasilkan keputusan atau hasil pemecahan dalam suatu masalah yang harus dihadapi dengan tegas [8]. Pengambilan keputusan berbeda dengan pemecahan masalah yang ditandai dengan situasi di mana tujuan ditetapkan dengan jelas dan bagaimana pencapaian sebuah target diuraikan menjadi sub tujuan, yang dapat membantu menjelaskan tindakan yang harus dan kapan diambil.

\section{METODE PENELITIAN}

\section{A. Desain Penelitian}

Penelitian menggunakan pendekatan pengambilan keputusan strategi Mintzberg et.al seperti Gambar 1 sebagai 
acuan dalam mencari tahu keputusan strategi pemasaran yang dibuat. Model penelitian yang digunakan pada penelitian ini bersifat deskriptif kualitatif. Strategi yang dilakukan dalam penelitian ini menggunakan strategi survei. Strategi survei yang dipilih yaitu wawancara secara mendalam dengan subjek penelitian yang sudah ditentukan. Dalam penelitian kualitatif ini ditekankan pada makna dan proses dan tidak terletak pada pengukuran dan pengujian sebagaimana pada kuantitatif.

\section{B. Lokasi dan Subjek Penelitian}

Penelitian ini dilakukan di perusahaan agribisnis kelor di Madura. Pemilihan lokasi menyesuaikan dengan alamat responden yang digunakan yaitu pemilik perusahaan produksi kelor. Pemilihan pemilik perusahaan sebagai informan karena kewenangan posisi yang diberikan untuk menentukan atau mengambil keputusan yang bersifat strategis [9]. Subjek dari penelitian ini adalah pemilik atau manajer pemasaran perusahaan kelor yang telah mengetauhi mengenai pemasaran atau penjualan kelor di perusahaannya.

\section{Pengumpulan dan Pengolahan Data}

Pengumpulan dan pengolahan data penelitian ini menggabungkan Mintzberg dan Miles \& Huberman [10]. Di mana setelah peneliti mendapatkan data hasil wawancara terhadap perusahaan kelor Madura, data diolah menggunakan reduksi data. Reduksi data merupakan proses dalam pemilihan, pemusatan perhatian pada penyederhanaan, transformasi data kasar yang muncul dari data yang ada di lapangan. Reduksi data adalah proses penggabungan dari data yang diperoleh menjadi satu bentuk tulisan yang akan dianalisis oleh peneliti selanjutnya. Data yang ada di reduksi dapat memberikan gambaran untuk pengumpulan data yang lebih spesifik dan mempermudah peneliti melakukan tahap yang selanjutnya. Setelah data telah melalui reduksi data. Data selanjutnya diolah berupa pemetaan untuk mengidentifikasi hasil wawancara menggunakan pendekatan pengambilan keputusan Mintzberg. Di dalam tahap ini terdapat tiga tahap yaitu identifikasi, pengembangan dan seleksi. Di tahap identifikasi terdapat dua sub-alur yaitu pengenalan dan diagnosis masalah atau kesempatan. Di tahap pengembangan terdapat sub-alur pencarian dan desain. Di tahap seleksi terdapat sub-alur judgment, analisis dan penawaran di mana dari ketiga sub-alur tersebut diplilih salah satu pemetaan dari hasil sub-alur sebelumnya yang terdapat pada tahap pengembangan. Untuk mendapatkan pandangan strategi pemasaran perusahaan kelor madura, analisis perbandingan pengambilan keputusan dan strategi pemasaran Kotler digunakan dalam penelitian ini.

\section{HASIL DAN PEMBAHASAN}

\section{A. Pemetaan Pengambilan Keputusan Strategi Pemasaran Perusahaan Kelor Madura}

Peneliti melakukan wawancara pada bulan Juni 2017 kepada pemilik perusahaan kelor Madura yang sudah berdiri sejak tahun 2011. Perusahaan ini mempunyai dua lini perusahaan yang bergerak di bidang produksi dan distribusi kelor. Cakupan pasar yang dimiliki oleh perusahaan ini meliputi pasar dalam dan luar negeri. Perusahaan kelor Madura mengawali strategi pemasaran kelor dengan melayani permintaan kelor di luar negeri. Permintaan kelor tersebut terjadi ketika perusahaan diminta oleh salah satu perusahaan yang berdomisili di Bangkok untuk mengirimkan produk turunan kelor berbentuk bubuk atau tepung. Untuk menyanggupi permintaan tersebut perusahaan mengembangkan strategi pemasaran global di mana pemilik perusahaan menemukan bahwa terdapat kriteria yang harus dipenuhi agar produk dapat diekspor ke pasar luar. Kriteria tersebut berupa peningkatan kualitas produk yang sesuai dengan ketentuan permintaan pasar. Perusahaan melihat korelasi permintaan tersebut dengan popularitas kelor di dalam negeri yang tidak terlalu dikenal masyarakat.

Keputusan judgment atau bersifat menghakimi dari pemilik perusahaan adalah pasar dalam negeri tidak dominan terhadap perkembangan kelor. Keputusan tersebut membuat perusahaan menyeleksi langkah-langkah strategi untuk mengenalkan kelor ke masyarakat dalam negeri. Perusahaan melakukan penjualan langsung kepada stakeholder yang mengerti mengenai manfaat kelor seperti menjalin kerjasama dengan pemerintahan setempat melalui pameran yang diadakan.

Strategi Word of Mouth atau rekomendasi produk dinilai perusahaan efektif dalam memasarkan produk perusahaan. Salah satunya yaitu dari pemerintah kepada pihak terkait seperti dinas kesehatan baik secara individu atau kelompok terhadap produk kelor bertujuan untuk memberikan informasi secara personal. Langkah strategi lain yang dilakukan perusahaan untuk memasarkan kelor secara nasional adalah diversifikasi produk menjadi beberapa bagian. Beberapa produk tersebut dijual dalam berbagai macam ukuran dan harga menyesuaikan pasar setiap produk. Untuk menjangkau pelanggan, perusahaan mengedarkan produk melalui

distributor yang ada di enam kota.

Hasil dari pengambilan keputusan tersebut membuat perusahaan mendapatkan permintaan tambahan dari luar negeri. Hasil tersebut mengembalikan perusahaan kepada identifikasi awal yaitu merevitalisasi Standard Operational Procedure (SOP) perusahaan baik dalam faktor produksi atau penjualan untuk mencapai target pasar Indonesia dan luar negeri. Revitalisasi SOP tersebut berdampak pada peningkatan kebutuhan produksi yang akan digunakan untuk memroses daun kelor basah yang memerlukan 1 ton daun kelor basah untuk diproses setiap harinya.

\section{B. Rangkuman Pengambilan Keputusan dan Strategi Pemasaran}

Terdapat enam indikator pada subjek pengambilan keputusan perusahaan kelor Madura seperti Tabel 1. Indikator tersebut yaitu identifikasi, pengumpulan dan analisis data, pembuatan alternatif, pemilihan alternatif, pelaksanaan keputusan, pemantauan dan pengevaluasian hasil pelaksanaan.

Sedangkan, bauran pemasaran yang digunakan untuk mengidentifikasi strategi pemasaran menggunakan bauran pemasaran manajemen marketing modern [7]. Bauran pemasaran tersebut adalah produk, harga, tempat, promosi, proses, orang dan performansi. Perusahaan kelor Madura menggunakan tempat atau saluran distribusi produk melalui dua lini yaitu offline atau secara nyata dan online atau dunia maya. Indikator promosi pada dua perusahaan menggunakan langsung (direct) dan tidak langsung (Indirect). 
Tabel 1.

Rangkuman Pengambilan Keputusan dan Strategi Pemasaran Perusahaan Kelor Madura

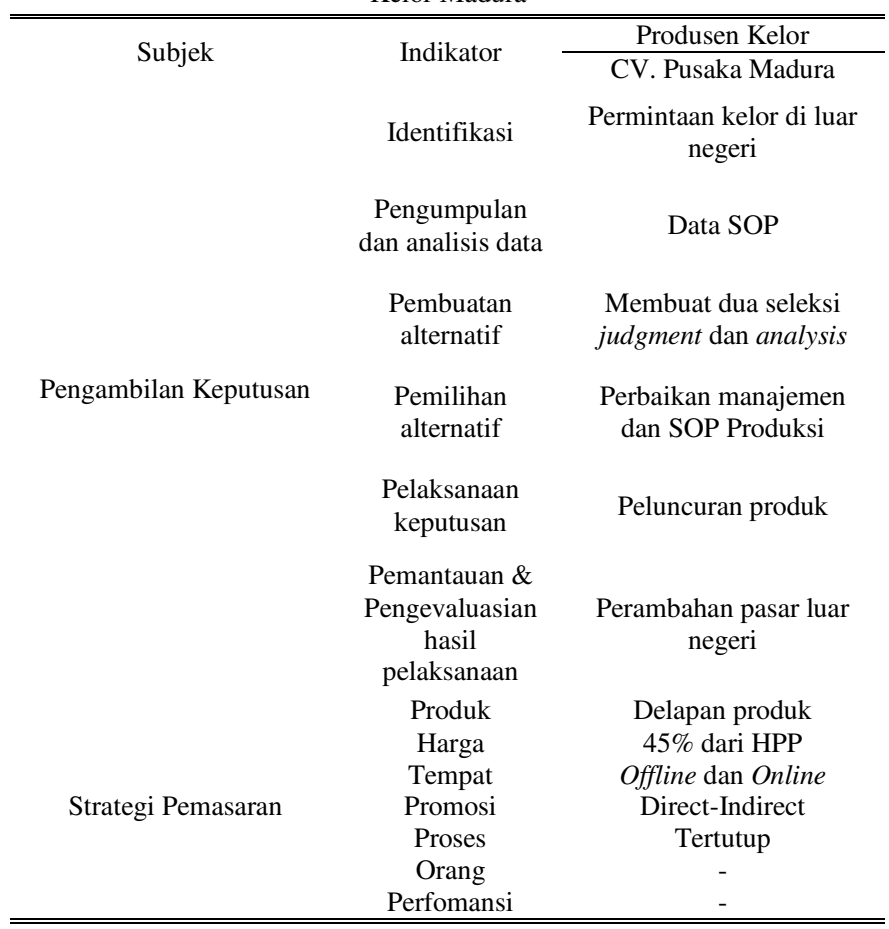

Dalam indikator performansi adalah pemasaran menyeluruh atau mencakup berbagai hasil pengukuran yang memiliki implikasi keuangan dan non-keuangan serta di luar perusahaan itu sendiri [11]. Perusahaan kelor Madura tidak memiliki bauran pemasaran performansi yang berupa pengukuran yang berkaitan dengan aspek teknologi atau intelijensia bisnis dan keuangan.

Pada indikator produk, perusahaan kelor Madura menjual delapan produk yang terbagi menjadi dua macam klasifikasi yaitu produk olahan seperti, tepung kelor, teh kelor, kerupuk kelor, kapsul kelor, ulir-ulir kelor dan stik kelor. Sedangkan, produk pertanian kelor yang dijual perusahaan adalah bibit kelor dan biji kelor. Perusahaan kelor Madura menetapkan harga jual setiap produk dengan rumus menambah marjin 45 persen dari Harga Pokok Produksi (HPP) setiap produk baik bubuk, teh, biji dan lain lain.

Di Indikator proses, perusahaan kelor Madura tidak melibatkan pelanggan dalam prosesnya, proses yang dilakukan perusahaan baik produksi hingga distribusi bersifat tertutup. Pada indikator orang, perusahaan kelor Madura menggunakan kuantitas produk sebagai nilai yang melibatkan baik pelanggan dan pekerja pelanggan sebagai bentuk pemasaran.

\section{Implikasi Manajerial}

Penelitian yang dilakukan merupakan suatu eksplorasi di mana hasil yang diperoleh diharapkan dapat dijadikan parameter dalam pertimbangan atau pun pengambilan keputusan. Hasil tersebut seperti yang terdapat pada Tabel 2 mengenai bauran pemasaran kelor. Di mana suatu model pengambilan keputusan atau strategi pemasaran yang diterapkan dapat diketahui mana yang sebaiknya digunakan dalam perusahaan kelor Madura khususnya agar dapat memperoleh hasil pengambilan keputusan yang baik.
Tabel 2.

Rangkuman Bauran Pemasaran Perusahaan Kelor Madura Bauran Pemasaran

Utama Perusahaan Kelor Madura

\begin{tabular}{rc}
\hline \hline Bauran Pemasaran & Perusahaan Kelor Madura \\
\hline Utama & Kandungan nutrisi \\
& \\
Dasar & Tepung kelor \\
& Biji kelor \\
& Bibit kelor
\end{tabular}

Produk

\begin{tabular}{ccc} 
& Diharapkan & Teh kantong kelor \\
& Tambahan & Stik kelor \\
& Ulir-ulir kelor \\
& Potensial & Mie kelor \\
& Cost Plus Pricing & Minuman teh botol kelor \\
& Method & Marjin 45\% dari Harga Pokok \\
Harga & Mark-up Pricing & Produksi \\
& Demand-oriented & - \\
& Pricing & Berdasarkan nego \\
Tempat & \\
& Saluran level nol & Facebook page \\
& Saluran satu level & Distributor perwakilan kota \\
& Saluran dua level & - \\
& Saluran tiga level & - \\
& Iklan (Ads) & - \\
Promosi & Word of mouth & Pelanggan lama-pelanggan baru \\
& Publisitas & Pameran dalam negeri \\
& Penjualan personal & Door-to-door \\
& Pemasaran langsung & Facebook fanpage \\
& Promosi penjualan & - \\
Orang & Pekerja & Lapangan pekerjaan baru \\
& Pelanggan & - \\
& Perfomansi & Tidak ada \\
& Proses & Tertutup \\
\hline \hline
\end{tabular}

Dapat dipastikan bahwa hasil dari penelitian ini memiliki implikasi yang positif bagi berbagai pihak yang tersangkut dalam penelitan ini. Dari berbagai macam permasalahan yang terjadi di ruang lingkup penelitian ini telah terungkap hasilhasil penelitian yang secara langsung berimbas terhadap pihak-pihak yang dimaksudkan. Salah satu diantaranya adalah hasil penelitian yang dibahas pada indikator performance di mana perusahaan agribisnis kelor masih kurang dalam memenuhi bauran pemasaran pada indikator tersebut.

Hal ini mengisyaratkan bahwa pihak manajemen perusahaan perlu memiliki suatu sistem pengukuran kinerja yang lebih baik agar dapat diterapkan pada perusahaan agribisnis kelor. Selain itu, dapat pula sebagai pengontrol manajemen yang berimplikasi pada bagian keuangan atau nonkeuangan serta komponen luar lainnya. Kemudian kepada manajemen juga diharapkan melengkapi komponen bauran pemasaran yang masih belum optimal agar terciptanya pemasaran kelor yang lebih masif dan terstruktur.

Pengambilan keputusan perusahaan mempunyai gaya pengambilan sendiri dan mempunyai pertimbangan seleksi alternatif keputusan yang diambil. Keputusan yang tersebut memberikan pandangan baru bagi pengusaha kelor lain agar dapat menyesuaikan dengan perusahaannya jika menghadapi permasalahan yang sama. Selain itu, setiap jalur pengambilan keputusan yang berbeda memberikan pandangan baru mengenai pengambilan keputusan yang tidak sembarangan. Di mana setiap perusahaan mengawali pengambilan keputusan dengan latar belakang permasalahan atau kesempatan yang berbeda. Selanjutnya, dilanjutkan dengan pengembangan dengan gaya perusahaan sendiri di mana hal ini juga 
dipengaruhi dengan nilai yang dibawa perusahan dan juga gaya kepemimpinan pemimpin perusahaan selaku pengambil keputusan.

Implikasi yang lain adalah mengenai bauran pemasaran yang digunakan oleh setiap perusahaan. Di mana terdapat perbedaan dan persamaan di antara kedua perusahaan. Untuk indikator product, price, process, people kedua perusahaan memiliki perbedaan dalam menerapakan strategi pemasaran. Sedangkan, untuk indikator place dan promotion kedua perusahaan memiliki persamaan. Sehingga hal ini secara tidak langusng menyatakan bahwa perusahaan memerlukan analisis yang cukup matang dalam memuat keputusan dalam hal strategi pemasaran mana yang layak digunakan dan memang akan memberikan hasil positif sesuai dengan tujuan pemasaran yang dimiiki perusahaan. Ini juga mendorong para pengusaha kelor yang bergerak di bidang yang sama untuk lebih mengeksplorasi dan lebih detil mengenai strategi pemasaran yang sebaiknya digunakan dalam memasarkan produk kelor ke pasar.

Hasil penelitian pengambilan keputusan strategi pemasaran kelor dengan menggunakan model Mintzberg ini dapat digunakan sebagai referensi para pengusaha kelor dalam menentukan pengambilan keputusan atau strategi pemasaran yang akan diterapkan. Oleh karena itu dengan pengambilan keputusan seperti ini, haruslah berhati-hati dalam mengambil sebuah keputusan yang berkaitan dengan strategi pemasaran. Di mana implikasi pemasaran sendiri terhadap produk perusahaan yang akan dikenalkan ke masyarakat apakah berdampak positif atau negatif.

\section{SIMPULAN DAN SARAN}

Berdasarkan hasil penelitian yang telah dieksplorasikan, pengambilan keputusan perusahaan kelor Madura berangkat dari permintaan pasar luar negeri mengenai ekspor kelor di Indonesia. Perusahaan mengembangkan pemasaran kelor nasional dengan memunculkan opsi-opsi yang akan diseleksi. Seleksi yang dipilih oleh perusahaan berupa perbaikan manajemen dan SOP produksi yang dilanjutkan dengan peluncuran produk secara bertahap dan konsinyasi reseller atau distributor yang ada di daerah lain. Hasil dari pengambilan keputusan tersebut perusahaan merambah kepada permintaan luar negeri dengan cara tetap merevitalisasi SOP perusahaan.

Strategi pemasaran kelor pada perusahaan agribisnis menggunakan analisis kualitatif di mana perusahaan kelor Madura berdasarkan tingkat produknya memenuhi ketiga tingkatan yaitu utama, dasar, diharapkan, tambahan, potensial dengan total sebanyak sepuluh produk. Dari aspek price berdasarkan metodenya perusahaan kelor Madura menggunakan dua metode yaitu Cost plus pricing dan Demand-oriented pricing. Untuk aspek place berdasarkan bentuknya perusahaan kelor Madura mendapatkan dua saluran yaitu saluran level nol dan satu level. Sementara aspek promotion berdasarkan bentuknya perusahaan kelor Madura memenuhi empat dari enam bentuk promosi. Sedangkan, untuk process dilihat dari bentuknya perusahaan kelor Madura bersifat tertutup terhadap prosesnya. Untuk aspek people berdasarkan perusahaan kelor Madura hanya memenuhi satu kategori yaitu pekerja dengan nilai kuantitas. Terakhir, untuk aspek performance tidak memenuhi karena perusahaan kelor Madura tidak mempunyai alat pengukuran kinerja baik yang bersifat keuangan atau non-keuangan perusahaan.

Batasan dalam penelitian ini adalah perlu dilakukan pengkajian lebih lanjut dalam penelitian kualitatif. Penyempurnaan metodologi dalam penelitian ini masih diperlukan. Untuk pengembangan riset dalam lingkup topik pengambilan keputusan atau strategi pemasaran kelor, saran yang dapat diberikan adalah penelitian mengenai Pengambilan keputusan atau pemasaran produk kelor masih sedikit dilakukan di Indonesia sehingga diharapkan penelitian seperti ini dapat dilanjutkan dan lebih banyak dilakukan seperti pengembangan strategi pemasaran kelor, pengambilan keputusan manajemen kelor dan pengaruh bauran pemasaran pada efektifitas strategi pemasaran kelor.

\section{DAFTAR PUSTAKA}

[1] Mathur, "Moringa for cattle fodder and plant growth," 2006. [Online]. Available: http://www.tfljournal.org/staticpages/index.php?page=call-forstudies-cattle-fodder.

[2] F. Kabugo, J. Oryokot, and J. Ssentumbwe, "Report of the Proceedings of the Stakeholders' Consultative Workshop on Moringa," Uganda, 2003.

[3] H. Mintzberg, D. Raisinghani, and A. Théorêt, "The Structure of 'Unstructured' Decision Processes," Adm. Sci. Q., vol. 21, no. 2, pp. 246$275,1976$.

[4] R. W. J. Keay, "Trees of Nigeria," Nord. J. Bot., vol. 322, 1989.

[5] O. F.O, N. Adikuru, and A. C. A, "Critical issues in Investment, Production and Marketing of Moringa oleifera as an Industrial Agricultural raw material in Nigeria," J. Agric. Res. Dev, 2011.

[6] P. Kotler and K. L. Keller, Marketing Management, 14th ed. New Jersey: Prentice Hall, 2012.

[7] M. S. Dagun, "Kamus Besar Ilmu Pengetahuan," Jakarta, 2006.

[8] H. Mintzberg, Rise and Fall of Strategic Planning. New York: The Free Press, 1994.

[9] M. Miles and M. A. Huberman, Analisis Data Kualitatif: Buku Sumber Tentang Metode-Metode Baru. Jakarta: UI Press, 1992.

[10] P. Kotler, S. H. Ang, S. M. Leong, and C. T. Tan, Manajemen pemasaran perspektif asia. Yogyakarta: Andi, 2000. 